\title{
MIĘDZY EKSPLANACJĄ A EKSPLIKACJĄ - PRZYCZYNEK DO METODOLOGII LINGWISTYKI. UWAGI NA MARGINESIE HISTORII HUMANISTYKI RENSA BODA
}

\author{
WŁADYSŁAW ZABROCKI
}

Dyskusja o statusie poznawczym humanistyki (w tym językoznawstwa) toczy się od czasu uformowania tej dziedziny wiedzy. Ostatnio spór został na nowo ożywiony dzięki pracy Rensa Boda De vergeten wetenschappen. Een geschiedenis van humaniora, 2010 (polskie thumaczenie holenderskiego oryginału ukazało się w 2013 w Wydawnictwie Aletheia pod tytułem Historia humanistyki. Zapomniane nauki.), a zwłaszcza angielskiemu tłumaczeniu, którego wydawcą jest Oxford University Press (w 2013 roku ukazała się wersja elektroniczna, w 2014 wersja w twardej okładce, a na styczeń 2016 jest planowane wydanie w miękkiej okładce). Należy podkreślić, że książka została omówiona na łamach Scientific American Volume 312, Issue $6 \mathrm{z}$ maja 2015, co jest bardzo rzadkie w przypadku humanistyki, a zwłaszcza jej historii. Widocznie redaktorzy tego renomowanego czasopisma popularyzującego naukę uznali doniosłość konkluzji rzeczonej pozycji. Efektem ożywionej działalności Rensa Boda jest też seria wydawnicza The Making of the Humanities I, II and III (2010, 2012, 2014) oraz zainicjowanie nowego czasopisma History of Humanities, którego pierwszy numer ukaże się w The University of Chicago Press na wiosnę 2016. Przedmiotem uwagi jest tam fundamentalna kwestia naukowego charakteru humanistyki. Zadanie realizowane w ramach wspomnianych przedsięwzięć to wykazanie, że humanistyka podobnie jak nauki przyrodnicze jest uprawiana jako dyscyplina 
empiryczna oraz stosuje uporządkowaną metodę prowadzącą do odkrywania zasad i regularności. Jest to szczegółowo w książce Rensa Boda dokumentowane na przykładach wziętych $\mathrm{z}$ humanistyki powstałej zarówno w kręgu kultury śródziemnomorsko-europejskiej jak i chińskiej oraz indyjskiej. Dzieło obejmuje ogromny obszar czasowy od starożytności do późnej nowoczesności. Autor ogranicza się do historiograficznego opisu dziejów humanistyki. Programowo abstrahuje od uwikłania w filozofię, czy zewnętrzne okoliczności społecznopolityczne.

W poniższych uwagach koncentrować się będę właśnie na zewnętrznych, filozoficzno-metodologicznych aspektach rozwoju humanistyki, w tym przede wszystkim językoznawstwa. Nawiasem mówiąc, warto zaznaczyć, że w bogatym dorobku Rensa Boda prace lingwistyczne zajmują szczególne miejsce. Chociaż sam autor tego nie mówi, analogii humanistyki z przyrodoznawstwem poszukuje na gruncie tak czy inaczej rozumianego wyjaśniania (por. Bod, 2005).

Celem mojego tekstu jest zasygnalizowanie, że naukowy charakter humanistyki (zwłaszcza językoznawstwa) jest związany także z przeprowadzaniem innej od wyjaśniania procedury, którą nazywam roboczo 'eksplikacją', często wbrew źródłowej semantyce tego pojęcia, która sięga jego twórcy - Rudolfa Carnapa. Być może ta różna od wyjaśniania procedura jest związana raczej ze światopoglądową funkcją humanistyki niż z poznawczą. Na obecność takiej procedury (różnej od wyjaśniania nomotetycznego) w językoznawstwie wskazywał na gruncie polskim Andrzej Bogusławski w fundamentalnym artykule opublikowany w Biuletynie Polskiego Towarzystwa Językoznawczego (Bogusławski, 1986), a rozwinął to stanowisko w kierunku fenomenologicznym Ireneusz Bobrowski (1993). Na ile hermeneutyczne stanowisko Esy Itkonena (1978) oraz neoplatońska postawa Jerrolda Katza (1981) są wyrazem podobnych wątpliwości co do statusu poznawczego lingwistyki postaram się pokazać w innym miejscu (Zabrocki, w przygotowaniu).

Konsekwentnym zwolennikiem uznania wyjaśniania za podstawową procedurę rozwiązywaną $\mathrm{w}$ językoznawstwie jest Tadeusz Zgółka, którego prace przynoszą ciekawe rekonstrukcje wyjaśnień podejmowanych na gruncie językoznawstwa strukturalistycznego (por. Zgółka, 1976) a także uwagi o zasadniczej roli tej procedury w językoznawstwie historyczno-porównawczym i generatywnym (por. zwłaszcza rozdział pierwszy autorstwa Zgółki w popularnym Wstępie do językoznawstwa (Bańczerowski, Pogonowski i Zgółka, 1982)), który powstał jako wynik prac poznańskiej szkoły językoznawczej. Na przykładzie tego podręcznika można wyraźnie zobaczyć napięcie między członami zawartej w tytule niniejszego artykułu opozycji. Znakomite rozdziały napisane przez Jerzego Bańczerowskiego chciałbym rozumieć jako wzorcowy przykład stosowania procedury eksplikacji. 
Stanowiska zajmowane w ramach podstaw językoznawstwa oscylują od początku tej nauki wokół sporu o autonomiczny charakter przedmiotu jej badań. Podobnie zdaje się ogniskować spór prowadzony w ramach innych działów humanistyki. Wskazać tu można na uwikłanie literaturoznawstwa, czy historii sztuki w dyskurs psychoanalityczny, a także np. uzależnienie historiografii od socjologii lub ekonomii. Wczesnemu usystematyzowaniu spór uległ w poglądach reprezentowanych przez przedstawicieli tzw. niemieckiej filozofii humanistyki. Należy tutaj wymienić Wilhelma Diltheya (1883) oraz Wilhelma Windelbanda (1904). Ich zdaniem naukowy charakter dociekań humanistów jest gwarantowany przez opozycyjną wobec przeprowadzanego w przyrodoznawstwie wyjaśniania procedurę zwaną 'rozumieniem'. Windelband podkreślał idiograficzny charakter humanistyki wobec nomotetycznego przyrodoznawstwa. Przedmiotem humanistyki mają być wartości w opozycji do faktów badanych przez nauki przyrodnicze. Innym sposobem zagwarantowania naukowego charakteru humanistyki są podejmowane niejednokrotnie próby redukcji jej przedmiotu do poszczególnych dyscyplin ugruntowanych empirycznie nauk przyrodniczych lub społecznych. Lingwistyka bywa sprowadzana do biologii (ewolucjonizm), psychologii (behawioryzm, czy współcześnie kognitywizm), czy nawet fizyki (akustyka, a współcześnie fizyka mózgu proponowana przez Chomsky'ego). Natomiast pozostałe dziedziny humanistyki często bywają odnoszone redukcyjnie właśnie do lingwistyki. Powstaje pytanie, czy mamy w opisanej sytuacji do czynienia z próbami redukcji eksplanacyjnej, co wydaje się być dosyć rozpowszechnionym przekonaniem. Moja propozycja zmierza do innego rozwiązania.

Metodologiczno-filozoficzna refleksja nad dziejami lingwistyki przynosi dwa stanowiska w kwestii paradygmatycznych podziałów w zakresie stosowanych przez językoznawców w praktyce badawczej procedur naukowych. Zgodnie $\mathrm{z}$ dominującym punktem widzenia wyrażanym wielokrotnie przez znanego historyka myśli lingwistycznej Konrada Koernera (zob. np. Koerner, 1982) w dziejach lingwistyki można odnotować szereg odrębnych nurtów myślenia (stylów myślowych w sensie Flecka, bądź paradygmatów w sensie Kuhna). W polskiej lingwistyce takie stanowisko zajmuje Ireneusz Bobrowski (por. np. popularny podręcznik Zaproszenie do językoznawstwa). Warto odnotować konkurencyjny wobec powyższego punkt widzenia, zgodnie z którym nie ma wystarczających przesłanek do zakładania paradygmatycznej zmienności w dziejach myśli językoznawczej (por. Percival, 1976).

Chciałbym zaznaczyć, że nie wiążę zróżnicowania paradygmatycznego z porządkiem chronologicznym. Nie przenoszę wizji Thomasa Kuhna o następowaniu po sobie kolejnych paradygmatów w cyklu obejmującym kolejne etapy nauki normalnej powstające w wyniku coraz to nowych rewolucji naukowych. Być może ma to miejsce w przypadku nauk przyrodniczych, będących przedmiotem 
uwagi w słynnej książce Kuhna (1962), natomiast nie występuje w historii nauk humanistycznych, gdzie na przykład w językoznawstwie znakomicie rozwijają się współcześnie (niejako równolegle) wyróżniane najczęściej w literaturze przedmiotu paradygmaty historyczno-porównawczy, strukturalistyczny, generatywny i kognitywny. Dopuszczam możliwość współwystępowania różnych stylów myśli lingwistycznej, wbrew diagnozie np. Jerzego Kmity (1978), czy oczekiwaniom Chomsky'ego (por. np. zdecydowane stanowisko Chomsky'ego wyrażone np. w: Andor, 2004), który dziwi się rozwojowi językoznawstwa korpusowego, zaznaczając, że leżące u jego podstaw założenia dawno zakwestionował i (jego zdaniem) przekonująco odrzucił. Co więcej, współczesne zróżnicowanie paradygmatyczne lingwistyki wydaje mi się wskazywać na cechę dystynktywną humanistyki w opozycji do przyrodoznawstwa i nauk formalnych (por. T. Batóg w kwestii zróżnicowania paradygmatycznego matematyki).

Kryteriów wyróżnienia paradygmatycznej zmienności myśli lingwistycznej poszukuje się w rozmaitych obszarach: założeń filozoficznych (naturalizm vs antynaturalizm - Chomsky'ego rozróżnienie na I-język i E-język), procedur wiążących fakty z teoriami (Bobrowski, 1998), stosowania różnych rodzajów wyjaśniania (por. np. Zabrocki, 2006 - wyjaśnianie przyczynowe i funkcjonalne). Podtrzymuję stanowisko o wyróżnianiu różnych rodzajów wyjaśniania w lingwistyce, ale zakładam, że jest to sposób uzasadniania przeprowadzany $\mathrm{w}$ ramach jednego szeroko rozumianego paradygmatu.

Poniżej będę stosować w charakterze kryterium podziału paradygmatycznego opozycję 'eksplanacja' vs 'eksplikacja'. Wydaje się, że stosowanie tych procedur jako głównych narzędzi porządkowania i uzasadniania twierdzeń językoznawczych pozwala na wyróżnienie dwóch zasadniczych nurtów w lingwistyce. Jeden z nich, którego uwieńczeniem jest gramatyka kognitywna (u Langackera eksplikacja terminów gramatycznych przy pomocy terminów wziętych $z$ teorii kategorii pojęciowych, u Wierzbickiej eksplikacja przy pomocy pojęć z zakresu teorii semantycznych indefinibiliów), wywodzi się z poszukiwań idealnego języka myśli, zakłada brak autonomii językoznawstwa, przyjmuje punkt widzenia, zgodnie z którym trzeba poszukiwać lepszej, prostszej aparatury pojęciowej dla eksplikacji zjawisk językowych. Tutaj także można sytuować antynaturalistyczne próby zrozumienia języka, jego funkcjonowania i struktury, a także te nurty w językoznawstwie, dla których celem jest opisanie struktury języka naturalnego w kategoriach wziętych z języka rachunków logicznych, czy teorii mnogości (np. pierwsze próby tworzenia gramatyki generatywnej przez Chomsky'ego włącznie z Syntactic structures). Drugi wielki nurt w dziejach lingwistyki jest związany z poszukiwaniem wyjaśnienia zjawisk językowych. Tutaj odnotujmy dociekania młodogramatyków i generatywistów ze szkoły Chomsky’ego od momentu ukonstytuowania się teorii standardowej. 
Komentarza wymaga przyjęty w niniejszej pracy sposób rozumienia procedur wyjaśniania i eksplikacji. Zwłaszcza ta druga procedura wymaga sprecyzowania. Standardowo eksplikacja jest rozumiana jako rodzaj definicji regulującej, gdzie uściśla się znaczenie pojęć poprzez przyjęcie jako języka eksplikującego narzędzia pozwalającego wyrazić bardziej precyzyjnie terminy definiowane. Często przywoływane jako języki eksplikujące są języki z zakresu podstaw matematyki. Dla nas ważne jest to, żeby przyjąć, iż w ramach eksplikacji dokonuje się czasem przekładu z jednego języka na inny, a czasem po prostu wprowadza się język innej teorii, czy nawet dyscypliny badawczej. Przy czym celem jest nie tylko uzyskanie większej precyzji, co realizacja takich celów poznawczych jak lepsze zrozumienie (zakładam tutaj relatywizację do idealnego podmiotu rozumiejącego, który może być rozmaicie definiowany) zagadnień będących przedmiotem eksplikacji. Można to osiągnąć również stosując jako język eksplikujący np. język teorii ewolucji (Schleicher i jego kontynuatorzy w nurcie zastosowań lingwistycznych psychologii ewolucyjnej: Pinker i Jackendoff, 2004), czy np. język teorii naturalnego metajęzyka semantycznego (Wierzbicka). Tym samym eksplikacja staje się jednym ze sposobów uzyskania lepszego wglądu w badany przedmiot. Inne metody prowadzące do tego celu proponują fenomenologowie, dla których narzędziem nie może być język (nie można, ich zdaniem, zrozumieć języka przy pomocy języka).

Procedura wyjaśniania jest uznawana dosyć powszechnie za główną procedurę rozwiązywaną w rozwiniętych naukach empirycznych w opozycji do formalnych, gdzie taką rolę spełnia dowodzenie. W humanistyce najczęściej rozumiana jest ta procedura $\mathrm{w}$ sensie nadanym jej przez Hempla i Oppenheima w klasycznym tekście z 1948 roku. Współczesna dyskusja nad wyjaśnianiem przynosi jednak wiele nowych interpretacji roli i kształtu tej procedury (por. np. Salmon, 2003). Na użytek tego artykułu przyjmę tylko, że wyjaśnianie jest szukaniem odpowiedzi na pytanie „dlaczego p?” i przynosi odpowiedź, która stanowi jakieś uzasadnienie dla „p”. W ramach tutaj rozważanej procedury eksplikacji zadawane może być pytanie w stylu , co poeta miał na myśli?”” (przy czym „poetą” może być też interpretujący „poezję” - w humanistyce używana jest często metanarracja, czy nawet metametanarracja), a odpowiedź służyć ma specyficznemu uzasadnieniu, które pozwoli lepiej rozumieć przedmiot dociekań humanistów, czyli ludzkie działania lub/oraz przekonania i pragnienia. $\mathrm{W}$ tym ujęciu eksplikacja nie jest ujmowana jako rodzaj definicji.

Warto w tym miejscu wskazać na popularne niegdyś, a dzisiaj nieco zapomniane dwa polskie podręczniki metodologii nauk humanistycznych, z których jeden, autorstwa Jerzego Kmity (1973), kładł duży nacisk na rolę wyjaśniania w humanistyce, a drugi, którego autorem był Tadeusz Pawłowski (1978), wskazywał na dużą rolę definicji eksplikującej w naukach humanistycznych. 
Wyjaśnianie bywa rozumiane jako procedura porządkująca system twierdzeń danej teorii, a także (w ramach modelu hipotetyczno-dedukcyjnego) jako procedura spełniająca rolę swoistego uzasadnienia dla zdań wyjaśnianych. Eksplikacja jest tutaj też rozumiana jako procedura wspomagająca uzasadnienie. Poprzez włączenie do systemu danej dyscypliny pojęć eksplikujących umożliwione zostaje uruchomienie np. procedury falsyfikacji już na gruncie nowej teorii. Procedura eksplikacji może polegać na dokonywaniu swoistego przekładu (przeniesienia) pojęcia wziętego $\mathrm{z}$ jedne teorii, opartej na określonych założeniach filozoficznych, na inne pojęcie wzięte z innej teorii - opartej na innych założeniach filozoficznych. Zakłada się możliwość wyboru w zakresie założeń filozoficznych. I tak np. fenomenologicznie ugruntowana eksplikacja prowadzi do innego rezultatu (uzyskanego po eksplikacji), niż np. fundowany neopozytywistycznie przekład na język fizykalny (nie język fizyki, tylko język odnoszący się do obiektów fizycznych).

Opozycja sygnalizowana $\mathrm{w}$ tytule artykułu ma wiele wymiarów, które należy łączyć z kolejnymi elementami perspektywy filozoficznej występującej od zarania myśli humanistycznej, w tym zwłaszcza rozważanej tutaj refleksji językoznawczej. Twórcze napięcie generowane jest od czasów Wilhelma von Humboldta przez wprowadzone przez niego kategorie ergon oraz energeia. Ta druga stanowi naturalną podstawę dla badań nad filogenezą (historią) języka lub nad ontogenezą (akwizycją, naturalnym przyswajaniem) języka.

Wydaje się, że, niejako modelowo (w sensie typu idealnego), badania nad wymienionymi dziedzinami prowadzone były przez szkołę młodogramatyczną (historia języka) oraz przez nurt generatywno-transformacyjny (akwizycja języka). Język rozumiany w aspekcie statycznym (jako ergon) był badany przez strukturalistów i kognitywistów (specyficzne podejście do historii języka u strukturalistów i kognitywistów - gdzie fakty historyczne są wtórne wobec systemu (strukturalizm) lub domen umysłowych (kognitywizm). Podkreślić należy, w aspekcie tytułowej opozycji, powiązanie normy nakazującej badanie języka jako ergon ze stosowaniem procedury eksplikacji i odpowiednio zakładanie normy o procesualnym, dynamicznym charakterze języka przez stosujących procedurę wyjaśniania $\mathrm{w}$ językoznawstwie.

\section{Bibliografia}

Andor, J. 2004. "The master and his performance: an interview with Noam Chomsky”. Intercultural Pragmatics 1.1. 93-111.

Bańczerowski, J., Pogonowski, J. i T. Zgółka. 1982. Wstęp do językoznawstwa. Poznań: Wydawnictwo Naukowe UAM.

Batóg, T. 1996. Dwa paradygmaty matematyki. Studium z dziejów i filozofii matematyki. Poznań: Wydawnictwo Naukowe UAM. 
Bobrowski, I. 1998. Zaproszenie do językoznawstwa. Kraków: Wydawnictwo Instytutu Języka Polskiego PAN.

Bobrowski, I. 1993. Językoznawstwo racjonalne. Z zagadnień teorii językoznawczej i metodologii opisów gramatycznych. Kraków: Wydawnictwo Instytutu Języka Polskiego PAN.

Bod, R. 2005. "Exemplar-based explanation”. W zbiorze: Magnani, L. (red.). Model-based reasoning in science and engineering. Boston: Kluwer Academic Publishers.

Bod, R. 2013. A new history of the humanities: the search for principles and patterns from antiquity to the present. Oxford: Oxford University Press.

Bogusławski, A. 1986. „O pojęciu wyjaśniania i wyjaśnianiu w lingwistyce”. Biuletyn Polskiego Towarzystwa Językoznawczego XL. 45-51.

Dilthey, W. 1883. Einleitung in die Geisteswissenschaften: Versuch einer Grundlegung für das Studium der Gesellschaft und der Geschichte. Leipzig: Duncker und Humblot.

Hempel, C.G. i P. Oppenheim. 1948. "Studies in the logic of explanation". Philosophy of Science 15. $135-175$.

Itkonen, E. 1978. Grammatical theory and metascience: a critical investigation into the methodological and philosophical foundations of "autonomous" linguistics. Amsterdam: John Benjamins.

Katz, J.J. 1981. Language and other abstract objects. Totowa, N.J: Rowman and Littlefield.

Kmita J. 1973. Wyktady z logiki i metodologii nauk. Warszawa: PWN.

Koerner, K. 1982. "The Schleicherian paradigm in linguistics". General Linguistics 22.1. 1-39.

Kuhn, T.S. 1962. The structure of scientific revolutions. 1st ed. Chicago: The University of Chicago Press.

Pawłowski, T. 1978. Tworzenie pojęć $i$ definiowanie $w$ naukach humanistycznych. Warszawa: PWN.

Percival, W. 1976. "The applicability of Kuhn's paradigms to the history of linguistics". Language 52.2. 285-294.

Pinker, S. i R. Jackendoff. 2005. "The faculty of language: what's special about it?". Cognition 95.2. 201-236.

Salmon, M. 2003. "Causal explanation of behavior". Philosophy of Science 70.4. 720-738.

Windelband, W. 1904. Geschichte und Naturwissenschaft. Rede zum Antritt des Rektorats der Kaiser-Wilhelms-Universität Strassburg, gehalten am 1 mai 1894. Strassburg: J.H. Ed. Heitz Heitz und Mündel.

Zabrocki, W. 2006. Psychologizm i socjologizm w dziejach transformacyjno-generatywnej refleksji nad językiem naturalnym. Stuttgart: Ernst Klett Sprachen.

Zgółka, T. 1976. O strukturalnym wyjaśnianiu faktów językowych. Warszawa/Poznań: PWN. 